\title{
Morphological variation and geographic distribution of Schizopetalon arcuatum Al-Shehbaz (Brassicaceae), a cryptic endemic species from the Atacama Region, Chile
}

\section{Variación morfológica y distribución geográfica de Schizopetalon arcuatum Al-Shehbaz (Brassicaceae), una especie endémica y críptica de la Región de Atacama, Chile}

\author{
Oscar Toro-Núñez ${ }^{1,2}$, Tomás Simón M. Flores ${ }^{1}$, Ihsan Al-Shehbaz ${ }^{3}$ \& Mark E. Mort ${ }^{2}$ \\ ${ }^{1}$ Universidad de Concepción, Departamento de Botánica, Facultad de Ciencias Naturales y Oceanográficas, Concepción, \\ Chile. \\ ${ }^{2}$ University of Kansas, Department of Ecology and Evolutionary Biology \& Biodiversity Institute, 1200 Sunnyside Ave., \\ ${ }^{3}$ Missouri Botanical Garden, 2345 Tower Grove Avenue, St. Louis, Missouri 63110, U.S.A. \\ Lawrence, Kansas 66045, U.S.A.
}

\begin{abstract}
RESUMEN
La presente nota ofrece una revisión de la distribución geográfica y variación morfológica de Schizopetalon arcuatum, dado que ambas variables han generado confusión en la identificación de esta especie críptica. Se espera que la información presentada ayude a resolver este problema en relación a sus especies vecinas o cercanamente relacionadas.
\end{abstract}

Schizopetalon Sims is one of the three genera (including Mathewsia and Atacama) of the endemic South American tribe Schizopetalae (Brassicaceae; Toro-Núñez et al. 2013, 2015). It comprises 10 species of annual plants that occur primarily in Chile, but one species (S. rupestre) is native to both Chile and Argentina (Al-Shehbaz 1989). Geographic distribution of this genus ranges from the southernmost limit of the Norte Grande in the Atacama Desert (26 S) through semiarid areas towards the Mediterranean scrub near Santiago and Valparaiso $\left(34^{\circ} \mathrm{S}\right)$. Species of Schizopetalon occur across a wide spectrum of arid ecoregions, ranging from sandy, coastal landscapes from the coast line to 800 $\mathrm{m}$ and those that occur along stony slopes in the Andes Mountains from 2000 to $3500 \mathrm{~m}$. Schizopetalon presents a distinctive morphology in the Brassicaceae family because its flowers are presumable moth-pollinated (slender-corolla tubes, white pinnatifid petals that open mostly during night, and pollen grains with a coarse surface reticulum) and its diverse array of fruit, seed and cotyledon structures (AlShehbaz l.c.).

S. arcuatum Al-Shehbaz, belongs to the group of coastal desert plants in Schizopetalon, being the less known species of the group in the Atacama Desert area (Toro-Nuñez et al. 2013). Since its recognition (Al-Shehbaz l.c.), this species has been differentiated in Schizopetalon by the combined presence of inflorescences completely bracteate throughout, strongly arcuate fruits, and compressed-ovate seeds with incumbent and straight cotyledons (Al-Shehbaz l.c.). Among other features, $S$. arcuatum has been characterized for its sparse to nearly glabrous pubescence, pinnatisect leaves and fruiting bracts, divaricate fruiting pedicels, toothlike nectar glands, smooth or nearly torulose fruits with uniseriate seeds in each valve.

While taxonomic treatment of $S$. arcuatum provides distinction from other species of Schizopetalon (AlShehbaz l.c.), misidentification of specimens has been recurrent with closely related or geographically proximate distributed species (S. biseriatum Phil., S. bipinnatifidum Phil., S. tenuifolium Phil., and S. maritimum Barnéoud). The main obstacle for the differentiation of $S$. arcuatum has been the limited knowledge of morphological variation, which is represented from the only known type specimen (Marticorena et al. 1803, holotype OS, isotype CONC). As a result, given the limited information about morphological variation, geographic distribution, and relative abundance of populations, the recognition of $S$. arcuatum as a valid species of Schizopetalon and its relevance as an endemic species for the Atacama Region remains yet difficult to assess (Squeo et al. 2008a).

Recent molecular studies based on nuclear and chloroplast DNA sequences suggest that specimens morphologically identified as $S$. arcuatum collected close to the type locality are retrieved strongly supported as monophyletic and separately from other Schizopetalon species/clades (Toro-Núñez et al. 2013). These results suggest that newly identified specimens will offer refined information related 
to the taxonomic stability of proposed diagnostic characters and a more precise account of geographic distribution of this species. Herein, using molecularly identified specimens and herbarium specimens from neighboring areas, we provided a reviewed account of the morphological variation and the potential geographic distribution of $S$. arcuatum.

\section{TAXONOMIC TREATMENT}

Schizopetalum arcuatum Al-Shehbaz, Harvard Pap. Botany 1: 34. 1989. TYPE: Chile. Prov. Atacama: Dept. Freirina, Camino a Carrizalillo por Quebrada Chañaral, $4 \mathrm{~km}$ SE de la junta del camino El Morado, $350 \mathrm{~m}, 28^{\circ} 57^{\prime} \mathrm{S}, 7^{\circ} 17^{\prime} \mathrm{W}$, 23 Oct. 1971, C. Marticorena, R. Rodríguez \& E. Weldt 1803 (holotype, OS!; isotype, CONC!, F!).

Annual herbs, sparsely pubescent throughout with dendritic or forked trichomes. Stems erect, branched proximately to medially, $7-25 \mathrm{~cm}$ tall. Basal leaves pinnatifid to bipinnatisect, shallowly to deeply dissected, 1.5-5.7 cm long; lateral lobes ovate to oblong, 2-5.7 mm long, 1-3 mm wide. Cauline leaves similar to basal but decreasing in size upward. Racemes ebracteate, lowermost flower to throughout bracteate, greatly elongated in fruit; bracts pinnatifid, 5.7-32 $\mathrm{mm}$ long; rachis straight to slightly flexuous; glabrous to sparsely pubescent. Fruiting pedicels stout, straight or recurved, divaricate to erect, glabrous sparsely pubescent, 3-14 $\mathrm{mm}$ long. Sepals sparsely to densely pubescent with fine dendritic trichomes, 5-10.7 mm long, 1-2.7 mm wide. Petals 7.7-18 mm long; claws 4.8-10 $\mathrm{mm}$ long. Nectar glands toothlike, $0.5-0.6 \mathrm{~mm}$ long in fruit. Filaments 5-8.7 mm long; anthers 1.7-3.4 mm long. Ovules 36-66. Fruits linear, smooth or only slightly torulose, linear or arcuate, latiseptate, $3.5-6.6 \mathrm{~cm}$ long, 1-2 mm wide; valves glabrous or pubescent with soft, dendritic or bifurcate trichomes, with a prominent midvein and anastomosing lateral veins; style 0.1-2.7 mm long; stigma lobes usually extending over valves. Seeds uniseriate, compressed, ovate, yellowish to dark brown, minutely reticulate, $0.8-1.3 \mathrm{~mm}$ long, 0.6-0.85 mm wide. Cotyledons oblong, undivided, incumbent.

\section{STUDIED SPECIMENS}

Schizopetalon arcuatum. CHILE, Región de Atacama, Prov. Huasco, camino a Carrizal Bajo desde Huasco, 40 m, $28^{\circ} 20^{\prime} 34.51^{\prime \prime} \mathrm{S}, 71^{\circ} 09^{\prime} 14.41^{\prime \prime}$ W. 27-VII-2010. Toro \& Lira 34 (KANU); cerca a camino secundario desde refinería de Huasco, 212 m, 28²9'55.22"S, 71¹4'31.92"W. 28-VII2010. Toro \& Lira 43 (KANU); camino a caleta Carrizalillo desde ruta 5 sur, $629 \mathrm{~m}, 28^{\circ} 29^{\prime} 55.22^{\prime \prime} \mathrm{S}, 71^{\circ} 14^{\prime} 31.92^{\prime \prime} \mathrm{W}$. 28-VII-2010. Toro \& Lira 48 (KANU); camino a caleta Carrizalillo por Quebrada Chañaral en localidad del tipo de $S$. arcuatum, $316 \mathrm{~m}, 28^{\circ} 56^{\prime} 49.39^{\prime}$ 'S, 71'17'09.42'”W. 28-VII-2010. Toro \& Lira 49 (KANU); camino de caleta Carrizalillo a Quebrada Honda, 35 m, 28²9'55.22'S, 71'14'31.92'”W, 28-VII-2010, Toro \& Lira 51 (KANU); $20 \mathrm{~km}$ N Huasco on the road to Carrizal Bajo, 8-IX-1991, von Bohlen 1350 (SGO); Choros Bajos a Carrizalillo. 4-IX2000. Muñoz 4083 (SGO); 25 km después de Chañar de Aceituno hacia cruce con Carrizalillo, VIII-1977, Muñoz, Meza \& Barrera 1164 (SGO); Costa de Huasco, 5 m, 2826'S, 71 $12^{\prime}$ 'W, 20-IX-1949, Behn s.n. (CONC, SGO, OSU); Huasco, $30 \mathrm{~m}, 28^{\circ} 28^{\prime} \mathrm{S}, 71^{\circ} 13^{\prime} \mathrm{W}$. 19-IX-1963. Monypenny s.n. (CONC).

Germination Time: August to October

Locality: Coastal dunes from northern sites of Huasco to southern Carrizalillo at the Atacama Region, including sandy dry gullies projected from this zone to inland areas.

TAXONOMIC KEY TO DISCRIMINATE $S$. ARCUATUM FROM ITS RELATED SPECIES

1. Fruit valves with coarse, unbranched or forked long stalked-trichomes mixed with much smaller 2-forked ones; seeds flattened; cotyledons twisted.

S. bipinnatifidum

1'. Fruit valves glabrous or uniformly pubescent with small, 1- or 2-forked trichomes; seeds plump or globose, if flattened then cotyledons not twisted.

2. Seeds globose; cotyledons deeply bifid, spirally twisted

S. maritimum

2'. Seeds oblong to ovate and flattened; cotyledons entire, straight.

3. Fruits straight, erect to divaricate; seeds biseriate

S. biseriatum

3'. Fruits usually arcuate or tortuous, often reflexed, rarely spreading; seeds uniseriate.

4. Lateral leaf lobes always bifid, $0.5-1 \mathrm{~mm}$ wide; stigma lobes divergent

S. tenuifolium

4'. Lateral leaf lobes usually not bifid, 1-3 $\mathrm{mm}$ wide; stigma lobes extended over the valves

S. arcuatum

\section{REMARKS}

Revision of specimens of $S$. arcuatum revealed consistency in most of diagnostic characters proposed by Al-Shehbaz (l.c.), especially in the shape of fruits (arcuate to linear), seed (flattened, oblong), and non-twisted cotyledons (incumbent). Nevertheless, new variation was detected in bracts along inflorescences, which ranges from ebracteate, only lowermost flowers, and fully bracteate in the analyzed specimens (Fig. 1A, B, C). As noted by Al-Shehbaz (l.c.), variation on levels of pubescence (glabrous to sparsely) along inflorescence rachis, fruiting pedicels and fruit valves, and leaf shape dissection (from shallowly to deeply pinnatifid or very close to pinnatisect) is also detected. Variation on pubescence showed some geographic association, where specimens from the northern part of the distribution range 
(Toro \& Lira 34 and 43, von Bohlen s.n., Monypenny s.n.) exhibited consistently glabrous structures, compared to the rest of populations which were more densely pubescent. In general, pubescence of fruit valves was mostly glabrous to sparsely pubescent, and variation towards uniformly pubescent was detected in populations from or close to the type locality (Toro \& Lira 49). Only one specimen (Muñoz 4083) exhibited the rare presence of different fruits with mixed levels of pubescence (glabrous and sparsely).

According to the described pattern of variation, the identification of $S$. arcuatum should be based exclusively on fruit and seed characters, leaving other vegetative characters (e.g. pubescence and inflorescence bracts) for referential use only. Misidentification was detected in specimens with no reproductive characters, for which taxonomic discrimination have relied on characters like the presence of ebracteated inflorescences (S. maritimum) or the presence of bipinnatifid leaves ( $S$. bipinnatifidum). Such situation seems associated to specimens collected at the limits of the geographic distribution inferred for S. arcuatum (Fig. 1D),

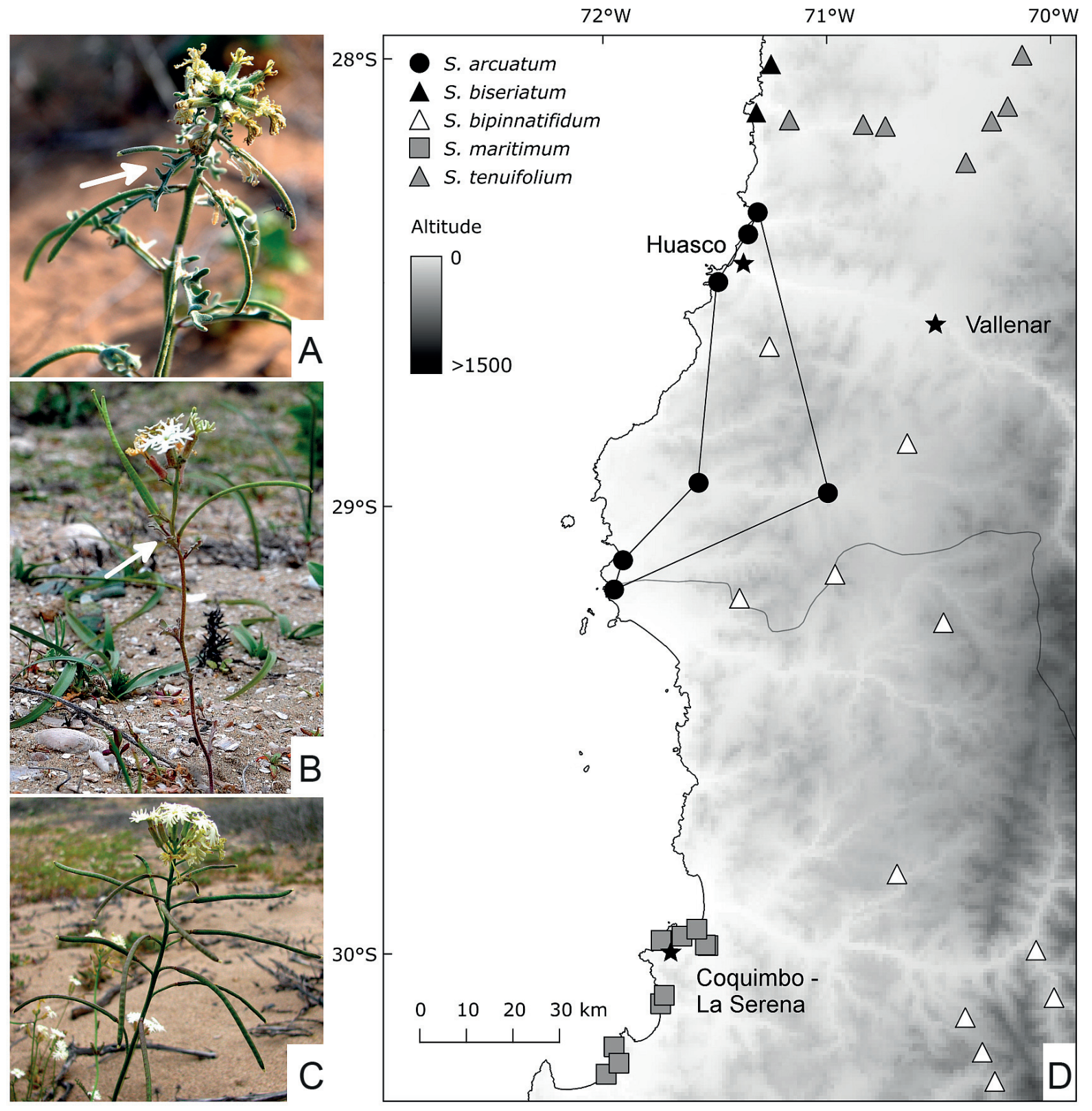

FIgURE 1. Display of fruit bracts (arrow) in racemes (A, B, C) from analyzed specimens of $S$. arcuatum, bracteate throughout (Toro \& Lira 48; A), uppermost bracteate (Toro \& Lira 51; B) and ebracteate (Toro \& Lira 43; C). Geographic distribution (D)/ Disposición de brácteas frutales (flechas) en los racimos de los especímenes analizados de S. arcuatum: completamente cubierto de brácteas (Toro \& Lira 48; A), solo con brácteas en la porción inferior (Toro \& Lira 51; B) y sin brácteas (Toro \& Lira 43;C). Distribución geográfica (D). 
which present high affinity with their neighbor species. This pattern could be explain by a combination of phenotypic plasticity due to border effect or current interspecific introgression; although, further data are required to test such hypothesis. Even though the presence of these patterns of variation, $S$. arcuatum is still readily discriminated for the unique combination of uniseriate fruits, oblong seeds with incumbent cotyledons, and arcuate fruits (Al-Shehbaz l.c.). These characters resemble with $S$. tenuifolium; nevertheless, this species is distinguishable from $S$. arcuatum because the presence of always bifid leaf lobes, divergent stigma lobes and disjoint distribution in the inland areas of the Atacama Region (Fig. 1D).

Localities from morphologically congruent specimens revealed a very restricted distribution (Fig. 1D), which suggest important implications for the conservation of $S$. arcuatum. The area of occurrence is delimited from the north shore of Huasco to the neighboring areas to the south of caleta Carrizalillo. Habitat of specimens suggests an almost exclusive occupation on dunes and sandy shores, except for a few populations located in inland gullies projected from the coastline (Fig. 1D). This distribution suggests that the occupation of $S$. arcuatum is overlapped with areas proposed for priority conservation, like Carrizalillo and Caleta Sarco (Squeo et al. 2008b).

\section{ACKNOWLEDGEMENTS}

CONAF Atacama and the administration of Parque Nacional Llanos del Challe for their logistic assistance in collecting field sampled specimens. This study was funded by FONDECYT postdoctoral project No 3160453 .

\section{REFERENCES}

Al-Shenbaz, I.A. 1989. Systematics and phylogeny of Schizopetalon (Brassicaceae). Harvard Papers in Botany 1:10-46.

Squeo, F.A., Arroyo, M.T.K., Marticorena, A., Arancio, G., MuÑoz-Schick, M., NegritTo, M., Rojas, G., Rodríguez, R., Humaña, A.M., Barrera, E., Marticorena, C. 2008a. Catálogo de la Flora Vascular de la Región de Atacama. En: Squeo, F.A., Arancio, G., \& Gutierrez, J.R. (eds.), Libro Rojo de la Flora Nativa y de los Sitios Prioritarios para su Conservación: Región de Atacama, pp 97 - 120. Ediciones Universidad de La Serena, La Serena, Chile.

Squeo, F.A., Letelier, L., Estévez, R.A., Cavieres, L.A., Minoc, M., López, D., Arancio, G. 2008b. Definición de los Sitios Prioritarios para la Conservación de la Flora Nativa de la Región de Atacama. En: Squeo, F.A., Arancio, G., \& Gutiérrez, J.R. (eds.), Libro Rojo de la Flora Nativa y de los Sitios Prioritarios de Conservación: Región de Atacama, pp. 137-163. Ediciones Universidad de La Serena, La Serena, Chile.

Toro-NúÑez, O., Al-Shehbaz, I.A., Mort, M.E. 2015. Phylogenetic study with nuclear and chloroplast data and ecological niche reveals Atacama (Brassicaceae), a new monotypic genus endemic from the Andes of the Atacama Desert, Chile. Plant Systematics and Evolution 301:1377-1396.

Toro-NúÑez, O., Mort, M.E., Ruiz-Ponce, E., Al-Shehbaz, I.A. 2013. Phylogenetic relationships of Mathewsia and Schizopetalon (Brassicaceae) inferred from nrDNA and cpDNA regions: taxonomic and evolutionary insights from an Atacama Desert lineage. Taxon 62: 343-356.

Recibido: 12.10 .2017

Aceptado: 24.01.2018 